\title{
AN ANALYSIS OF STUDENTS' SCANNING SKILL IN READING TEXT AT SECOND GRADE STUDENTS OF MTS THAMRIN YAHYA RAMBAH HILIR
}

\author{
Wirda Jannatul Jannah \\ wirdajannatuljannah@gmail.com \\ University of Pasir Pengaraian, Indonesia,
}

\begin{abstract}
The purpose of this research was to find out the second-grade students scanning skill in the reading text at MTs Thamrin Yahya Rambah Hilir. The research design was descriptive qualitative. The population was second-grade students with a total number of 77 students and the sample were 26 students. The sample was taken by cluster random sampling. In collecting the data the researcher used reading test it was narrative text to got the data. In analyzing the data the researcher used the components of Narrative Text such as Orientation, Complication, and Resolution. Based on the result of the analysis, the researcher found 4 students $(15,3 \%)$ had an excellent level, 7 students $(26,9 \%)$ had a good level, 11 students $(42,3 \%)$ had an average level, and 4 students $(15,3 \%)$ had fair level and there were no students who got poor category. It means that students' scanning skill in the narrative text at second-grade students of MTs Thamrin Yahya was average.
\end{abstract}

Keywords: Reading, Scanning, and Narrative text

\section{INTRODUCTION}

Reading skill has an important role in obtaining information. In every activity of English learners, they need reading skill. Reading is also the most important skill for EFL learners especially in academic context because students need to comprehend and deal with all reading aspect and difficulties. According to Cellik (2018), reading in a very basic term can be defined as recognizing the words, including the spelling, and the relations to other words in a sentence. It means that individuals, in this case, the students, have to understand and interpret the meaning of words or symbols in a text to achieve their own goals or interests.

An efficient reader should be able to locate portions of material that fulfil the reader purpose and skip those portions which do not. Such as when reading some of the stories, magazine, encyclopedia, newspaper and so on. In the reading text, many techniques will allow the reader to read selectively reading what is important 
and skipping what does not suit the reader immediate purpose. One of the techniques is scanning, the technique of rapidly locating particular types of information. In typically scan the text for specific information or a specific word. According to Sarwono (2013:2), scanning is a technique used to find specific information by looking at the text to find the information we need. The students of MTs Thamrin Yahya learn reading for six levels. Start from the first semester up to six semesters. The narrative text is one kind of text that they have learned.

The narrative text is the text tells about the imaginative story and has the purpose to entertain the readers. The narrative text is a description of events. The examples of the narrative text are folk tales, legend, fairy story, mystery, fables, historical narrative and ballads. Even though the students have learned English for a long time their abilities are still low. Based on the researcher observation at second-grade students of MTs Thamrin Yahya they still have many difficulties in reading texts such as the students often spend much time to answer reading text in the test, because the students have to read all of the text. The student quickly forgot what they have read, because the students have to read all of the text. The last, students do not understand the meaning of the words because the students have a limited vocabulary.

Based on the explanation above, the researcher was interested and want to analyze the students' skill in reading text by scanning technique. That is a way or technique to reading quickly and efficiently needed to overcome the problem above. Further, the purpose of this research was to find out the students scanning skill in the reading text at MTs Thamrin Yahya Rambah Hilir.

\section{REVIEW OF RELATED LITERATURES}

\section{Definition of Reading}

McWhorter (1992:131) states that reading is primarily a thinking process. They are, however, physical aspects of reading: your eyes recognize words and transmit them in the form of signals to the brain. In another word, Goodman (1969:137), mentioned reading as a receptive language process. It is a psycholinguistic process in that it starts with a linguistic surface representation 
encoded by a writer and ends with meaning which the reader constructs. Moreover, McWhorter (1992:165) defines reading as a complex process: it involves much more than adding word meanings together. Reading involves not only understanding ideas, but also recognizing the relationship and structures among ideas. It means in reading the reader not only read the text but the readers have to know the meaning of the text.

Based on the theories above, it can be concluded that reading is one of the basic skills in learning a language, it is an active process follow by physical activities such as an eye movement when the reader reads the passage. Reading does not just understand the words or the grammar, it is a thinking process. In other words, we call it comprehension. Comprehension is a mental process which will be found in the mind of the reader who reads the written material. Comprehension is the reader understanding of the meaning of the printed language.

There are some essential aspects of the processing of reading comprehension. According to King and Stanley (2004:8), they are:
(1) The main idea, According to Flemming (2011: 184), the main idea is the general comment or point the author wants to make about the topic. It's the overall message readers are expected to take from a reading.

(2) Finding factual information/ details, Factual information requires readers to scan specific details. There are many types of the question of factual information such as; question type of reason, purpose, result, and comparison, mean, identify, time and amount. In which most of the answer can be found in the text.

(3) Vocabulary, Penny in Kurniati (2015, p. 9), vocabulary is one of the extreme aspects that support speaking activity. It means vocabulary refers to words the reader needs to know to communicate with others.

(4) Reference, According to Assadi and Aidinlou (2012) said that reference is the set of grammatical resources that allow the speaker to indicate whether something is being repeated from somewhere earlier in the text. 
(5) Making inference, Mikulecky (1996, p. 150) says that inference is sometimes the topic of a text may not be stated anywhere directly. The reader must look for clues and try to guess what the passage is about. It means that the conclusion reached to have an opinion based on information and evidence.

\section{Scanning}

Scanning is to cover a great deal of material rapidly to locate a specific piece of information. It means scanning useful to find a specific name, date, statistic, and fact without reading the whole text. According to McWhorter (1992:106), scanning in reading is a technique for quickly looking through reading matter to locate a particular piece of information- a fact, a date, a name. you might be looking for the answer the question or for a fact or detail that you need to complete an assignment.

Scanning is a technique used to find specific information by looking at the text to find the information we need (Sarwono, 2013:2). Brown (2001:293) also said that scanning is quickly searching for a particular piece or pieces information in a text. The purpose of scanning is to the extent of specific information without reading through the whole text. When scanning the reader does not start from the beginning and read to the end. Instead, what the reader does is jump around in the text, trying to find the information that is needed. Scanning involves moving eyes cross down the text seeking the specific phrase or words. It means scanning is a technique for quickly finding specific information in a text. Based on the theories above, the researcher concludes that scanning involves moving our eyes quickly down the page seeking specific words and phrases.

\section{a. Steps to Scanning}

The key to effective scanning is to approach the material systematically. Many steps or ways to scanning developed by experts such as, according to Brown (2001:312) there are four steps to scanning they are, observe how the information is organized in the ads, read the text carefully to understand what is being asked to locate the information the reader need, move the eyes quickly over the printed page and paying attention to bold headlines and keywords. According to Caravella (2006:3), there are some steps to scanning such as state the specific information you 
are looking for, try to anticipate how the answer will appear and what clues you might use to help locate the answer. For example, if the reader were looking for a certain date, would quickly read the paragraph looking only for numbers and use headings and any other aids that will help to identify which sections might contain the information are looking for. Fourth selectively read and skip through sections of the passage. Furthermore, McWhorter (1992:107) states that there are some steps to scanning such as check the organization, form a specific question, anticipate word clues, identify answer locations, use a systematic pattern and confirm the answer.

\section{Nature of Narrative Text}

The narrative text is the text tells about the imaginary story. There are many types of narrative text like romance, mystery, horror and comedy. According to Nursahid and Mutaqin in Yanti (2015:6) narrative text is

\section{METHODS}

This research design was descriptive qualitative research. According to Creswell in Sugiyono (2013:14), qualitative research is a means for exploring and understanding the meaning individuals or groups ascribe the kind of that relates the story of acts or events. The narrative text includes occurrences in time and tells what happened according to natural time sequence. Types of the narrative text include short stories, novels, and news stories, as well as a large part of our everyday social interchange in the form of letters and conversations. Narrative text always deals with some problems which lead to the climax and the turn into a solution to the problem (Sudarwati and Grace, 2007:62). Moreover, Narratives are understood as stories that in clued a temporal ordering of events an effort to make something out of those events: to render, or to signify, the experiences of persons-in-flux in a personally and culturally coherent, plausible manner (Sandelowski, 1991:2). In addition, Mulyati in Noviani (2015: 15) defines narrative text is the text which retells a story or the event before it.

to a social or human problem. The process of research involves emerging questions and procedures; collecting data in the participants' setting: analyzing the data inductively, building from particulars to 
general themes; and making interpretations of the meaning of data. The final written report a flexible writing structure.

For getting the data the researcher gave the narrative text to students. Then, the researcher gave instruction students to use scanning skill for reading the text. After that, the researcher asked students to write down the detail information of the text. The last, the data were analyzed by using Sudarwati and Grace theory.

student's scanning skill, the researchers identified all of the data based on Sudarwati and Grace theory and to describe the value of student's scanning skill in the reading of narrative text the researcher described them with the following table:

Table 1

Range of the Score

\begin{tabular}{c|c}
\hline Rang of the score & The level of the skill \\
\hline $81-100$ & Excellent \\
\hline $61-80$ & Good \\
\hline $41-60$ & Average \\
\hline $21-40$ & Fair \\
\hline $0-20$ & Poor \\
\hline
\end{tabular}

Harris in Afrifa (2015:2)

After conducting the research, the researcher collected the data by using the test. To know the data description, the researcher could explain the students' correct answer and the score of the test by following the table below: 
Table 2

Students scanning skill score

\begin{tabular}{|c|c|c|c|c|}
\hline No & Name & $\begin{array}{l}\text { Correct } \\
\text { Answer }\end{array}$ & Total Score & Classification \\
\hline 1 & S1 & 6 & 46.1 & Average \\
\hline 2 & S2 & 7 & 53.8 & Average \\
\hline 3 & S3 & 6 & 46.1 & Average \\
\hline 4 & S4 & 10 & 76.9 & Good \\
\hline 5 & S5 & 7 & 53.8 & Average \\
\hline 6 & S6 & 11 & 84.6 & Excellent \\
\hline 7 & S7 & 10 & 76.9 & Good \\
\hline 8 & S8 & 7 & 53.8 & Average \\
\hline 9 & S9 & 9 & 69.2 & Good \\
\hline 10 & S10 & 6 & 46.1 & Average \\
\hline 11 & S11 & 5 & 38.4 & Fair \\
\hline 12 & S12 & 5 & 38.4 & Fair \\
\hline 13 & S13 & 5 & 38.4 & Fair \\
\hline 14 & S14 & 9 & 69.2 & Good \\
\hline 15 & S15 & 6 & 46.1 & Average \\
\hline 16 & S16 & 5 & 38.4 & Fair \\
\hline 17 & S17 & 12 & 92.3 & Excellent \\
\hline 18 & S18 & 11 & 84.6 & Excellent \\
\hline 19 & S19 & 9 & 69.2 & Good \\
\hline 20 & S20 & 7 & 53.8 & Average \\
\hline 21 & S21 & 11 & 84.6 & Excellent \\
\hline 22 & S22 & 6 & 46.1 & Average \\
\hline 23 & $\mathrm{~S} 23$ & 8 & 61.5 & Good \\
\hline 24 & S24 & 8 & 61.5 & Good \\
\hline 25 & S25 & 6 & 46.1 & Average \\
\hline \multirow[t]{3}{*}{26} & S26 & 6 & 46.1 & Average \\
\hline & Total & 198 & 1522 & \\
\hline & Average & & 58.5 & \\
\hline
\end{tabular}

JEE (Journal of English Education) Vol. 6 No. 2, December 2020

http://journal.upp.ac.id/index.php/JEE

P-ISSN:2459-9719, E-ISSN 2597-7091

DOL: https://doi.org/10.30606/jee 
Based on the table, it can be seen that the average of students scanning skill in reading the narrative text was 58.5 . It means, the students scanning skill in the narrative text were average level.
Moreover, based on table 2, the researcher could explain about the percentage of students' score in using a scanning technique in narrative text. The explanation could be seen in the table below:

Table 3

Percentage of students score in scanning narrative text

\begin{tabular}{c|c|c|c|c}
\hline No & Range Score & Frequency & Percentage & ability level \\
\hline 1 & $81-100$ & 4 & $15,3 \%$ & Excellent \\
\hline 2 & $61-80$ & 7 & $26,9 \%$ & Good \\
\hline 3 & $41-60$ & 11 & $42,3 \%$ & Average \\
\hline 4 & $21-40$ & 4 & $15,3 \%$ & Fair \\
\hline 5 & $0-20$ & 0 & 0 & Poor \\
\hline & Total & 26 & $100 \%$ & \\
\hline
\end{tabular}

Table 3 shows that from 26 students who took the test, 4 students $(15,3 \%)$ were in excellent level because they could answer the test correctly. 7 students $(26,9 \%)$ were at a good level, 11 students $(42,3 \%)$ were at an average level, and 4 students $(15,3 \%)$ were in fair level. There was no student in the poor category. It means that students' scanning skill in the narrative text as average level.

\section{Discussion}

In this research, the second-grade students of MTs Thamrin Yahya Rambah Hilir used scanning skill. The target of the research was the student's scanning skill reaches correct answer13 indicators. But in fact, they did not get reach the indicators. In this case, the researcher explained the factors of the result of students. The finding showed that of the result students' scanning skill in reading narrative text, there were only 4 students got excellent they reached 81-100 score. Because most of the students did not seriously when they did the test. In addition, students did not master about scanning. There were 4 students got a fair level. They reached 21-40 score. This is caused by a lack of concentration in scanning. There were 7 students got good level. They reached 61-80 score. This is caused by a lack of understanding in 
scanning the text. There 11 students at an average level. They got 41-60 score. This is caused by most of the students did not get all the indicators. From the explanation above, the researcher

\section{CONCLUSION}

Based on the result of research and discussion that has been presented in the previous chapter, it can be concluded that student's scanning skill in reading the narrative text of fable at second-grade students of MTs Thamrin Yahya Rambah Hilir was an average level. From 26 students, 4 students got an excellent score. 7 students got good level. There 11 students at the concluded that the student's scanning skill at second-grade students of MTs Thamrin Yahya Rambah Hilir was an average level.

average level. And there were 4 students got a fair level. So, the researcher can conclude that student's scanning skill at second-grade students of MTs Thamrin Yahya Rambah Hilir was score average level. Based on the findings of the research, it can be concluded that using the scanning technique is quite successful. It can be seen on the table of student's reading scores.

\section{ACKNOWLEDGEMENT}

Praised to the Almighty God for His blessing in this present paper. The writers hope that and guidance that this research paper can be finished. The writer also wants to thank all people who have assisted the writers in finishing this paper especially the this paper can be fruitful for all the readers and hopefully this paper can be the reference for the next researchers who are willing to research in the same field.

researchers whose writing are used and cited

\section{REFERENCES}

Assadi Nader ,Aidinlou. 2012. The Effect of textual Cohesive Reverence Instruction on the Reading Comprehension of Iranian EFL Students. International Journal of English linguistics Vol. 2 No. 5 
Brown, H. D. (2001).Teaching by Principles an Interactive Approach to Language Pedagogy. San Francisco: Longman

Caravella, J. (2006). A needs assessment method for Extension educators. Journal of Extension Vol. 44 No. 1 Article 1TOT2

Celik, B. (2018). Effects of Extensive Reading on Learners: How It Develops Certain Points in Vocabulary and Sentence Structure. International Journal of English Linguistics. Vol. 8 No. 2

Flemming, L. (2001). Reading For Result. Boston: Wadsworth Cengage Learnig.

Goodman, K. (1996). On reading. Portsmouth, NH: Heinemann

Kurniati, N. (2015). An analysis of student' reading speed of descriptive text at VIII grade SMPN 1 Rambah Samo. Unpublished Thesis: University of Pasir Pengaraian.

King, C. M., and Stanley, L. M. (2004). Teaching Readinf Skill in a foreign Language. Oxford: Oxford University Press

McWhorter.K. T. (1992). Efficient and flexible reading (3rd Ed). Niagara Country Community College: Harper Collins Publisher

Mikulecky, S. Beatrice.(1996). More Reading Power 2\# edition. New York: Pearson Education Inc

Noviani,A. (2015). An analysis of students' Writing Skill in Narrative Text at second grade students' of SMAN 3 Rambah Hilir. Unpublished Thesis: University of Pasir Pengaraian.

Sadelewoski, M. (1991). Telling Stories: Narrative Approaches in Qualitative research. IMAGE: Journal of Nursing Scholarship. Vol. 23, No. 3

Sarwono, jonathan \& Purwanto, yudhy. (2013).English for Academic Purposes. Yogyakarta.ANDI Yogyakarta.

Sudarwati, (2007). Look Ahead. Jakarta: Erlangga

Sugiyono. (2007). Metode Penelitian Kuantitatif, Kualitatif Dan Kombinasi (mixed methods).Bandung. Alfabeta.

Yanti,R. (2015). An analysis of preposition in narrative text at second grade students of MAN Pasir Pengaraian Kabupaten Rokan Hulu. Unpublished Thesis: University of Pasir Pengaraian. 